\section{Russell Sage Foundation African Immigration Research Initiative}

The Russell Sage Foundation is currently developing a new initiative on non-traditional destinations for immigrants to the US. The first phase of this initiative is a conference to be held at the Foundation's offices in NewYork, New York in February 2005.
ASA News readers are invited to visit the Russell Sage Foundation website for information about the conference and about the Foundation's immigration research program initiatives related to Africa: www.russellsage.org. For more information, contact: Abigail N Jackson, Program Assistant, Russell Sage Foundation, Tel: 212-750-6083; Fax: 212688-3993; Email: abigail@ @sage.org.

\title{
Awards and Fellowships
}

\section{National Endowment for Democracy (NED) Fellowships}

The National Endowment for Democracy (NED) invites applications to its Reagan-Fascell Democracy Fellows Program. Established in 2001 to enable activists, scholars, and journalists from around the world to deepen their understanding of democracy and enhance their ability to promote democratic change, the fellowship program is based at NED's International Forum for Democratic Studies, in Washington, D.C.

Program: The program offers two tracks: a practitioner track (typically three to five months) to improve strategies and techniques for building democracy abroad and to exchange ideas and experiences with counterparts in the United States; and a scholarly track (typically five to ten months) to conduct original research for publication. Projects may focus on the political, social, economic, legal, and cultural aspects of democratic development and include a range of methodologies and approaches.

Eligibility: The Reagan-Fascell Democracy Fellows Program is intended primarily to support practitioners and scholars from new and aspiring democracies.

Distinguished scholars from the United States and other established democracies are also eligible to apply.

Practitioners are expected to have substantial experience working to promote democracy. Scholars are expected to have a doctorate, or academic equivalent, at the time of application. The program is not designed to support students working toward a degree. A working knowledge of English is an important prerequisite for participation in the program.

Support: The fellowship year begins October 1 and runs through July 31, with major entry dates in October and March. All fellows receive a monthly stipend, health insurance, travel assistance, and research support through the Forum's Democracy Resource Center and Internship Program.

Application: For further details and instructions on how to apply, please download the "Information and Application Forms" booklet available online at www.ned.org/forum/RFApplication.pdf or visit www.ned.org and follow the link to Fellowship Programs. Please note that all application materials must be type-written and in English.

Deadline: Applications for fellowships in 2005-2006 must be received no later than November 1, 2004. Notification of the competition outcome is in April 2005. For questions, please contact: Program Assistant, Fellowship Programs, National Endowment for Democracy, 1101 15th Street, N.W., Suite 800, Washington, DC 20005; Tel.: 202293-0300; Fax: 202-293-0258; E-mail: fellowships@ned.org; Internet: www.ned.org.

\section{Scholar Rescue Fund 2004-2005 Fellowships}

The Institute of International Education's Scholar Rescue Fund provides fellowships for scholars whose lives and work are threatened in their home countries. These fellowships permit scholars to find temporary refuge at universities and colleges anywhere in the world, enabling them to pursue their academic work and to continue to share their knowledge with students, colleagues, and the community at large. When conditions improve, these scholars will return home to help rebuild universities and societies ravaged by fear, conflict and repression.

How the Scholar Rescue Fund Works:

Academics, researchers and independent scholars from any country, field or discipline may qualify. Preference is given to scholars with a PhD or other highest degree in their field; who have been employed in scholarly activities at a university, college or other institution of higher learning during the last four years (excluding displacement or prohibition); who demonstrate superior academic accomplishment or promise; and whose selection is likely to benefit the academic community in the home and/or host country or region. Applications from female scholars and under-represented groups are strongly encouraged.

Universities, colleges and research centers in any country may apply to serve as hosts.

Applications and nominations should be made to the Fund's Selection Committee. Institutions interested in hosting a particular scholar should submit a letter with the scholar's application. Fellowships are awarded to institutions for support of specific individuals, to be matched in most cases by the institution or third-party. Fellowship recipients are expected to continue their work in safety at the host institution-teaching, lecturing, conducting research, writing and publishing. Fellowships from 3 months to one calendar year will be considered with up to 25 fellowships awarded annually. The maximum award is 